\title{
REVIEW
}

\section{Optimising pharmacological maintenance treatment for COPD in primary care}

\author{
*Rupert Jonesa ${ }^{\mathrm{a}}$, Anders Østrem ${ }^{\mathrm{b}}$ \\ a Respiratory Research Unit, Peninsula Medical School, University of Plymouth, UK \\ ${ }^{\mathrm{b}}$ Gransdalen Legesenter, Gransdalen, Oslo, Norway
}

Originally submitted 3rd February 2010; revised version received 15th June 2010; accepted 9th September 2010; online 19th November 2010

\begin{abstract}
Chronic obstructive pulmonary disease (COPD) is a multi-faceted disease that is a major cause of morbidity and mortality worldwide, and is a significant burden in terms of healthcare resource utilisation and cost. Despite the availability of national and international guidelines, and effective, well-tolerated pharmacological treatments, COPD remains substantially under-diagnosed and under-treated within primary care. As COPD is both preventable and treatable there is an urgent need to raise the awareness and profile of the disease among primary care physicians and patients. Increasing evidence suggests that initiation of long-acting bronchodilator treatment at an early stage can significantly improve the patient's long-term health and quality of life (QoL). Recent large-scale trials in COPD have confirmed the longterm benefits of maintenance treatment with long-acting bronchodilators. A wide range of benefits have been shown in selected patient groups including improved lung function and QoL, reduced exacerbations and, in some studies, delayed disease progression and improved survival. In this review, we consider recent developments in our understanding of COPD, including current and emerging pharmacological treatment options, and identify steps for optimising early diagnosis and pharmacological treatment of COPD within the primary care environment.

(C) 2011 Primary Care Respiratory Society UK. All rights reserved.

R Jones and A Østrem. Prim Care Respir J 2011; 20(1): 33-45

doi:10.4104/pcrj.2010.00069
\end{abstract}

Keywords COPD, primary care, exacerbations, diagnosis, treatment, guideline, management

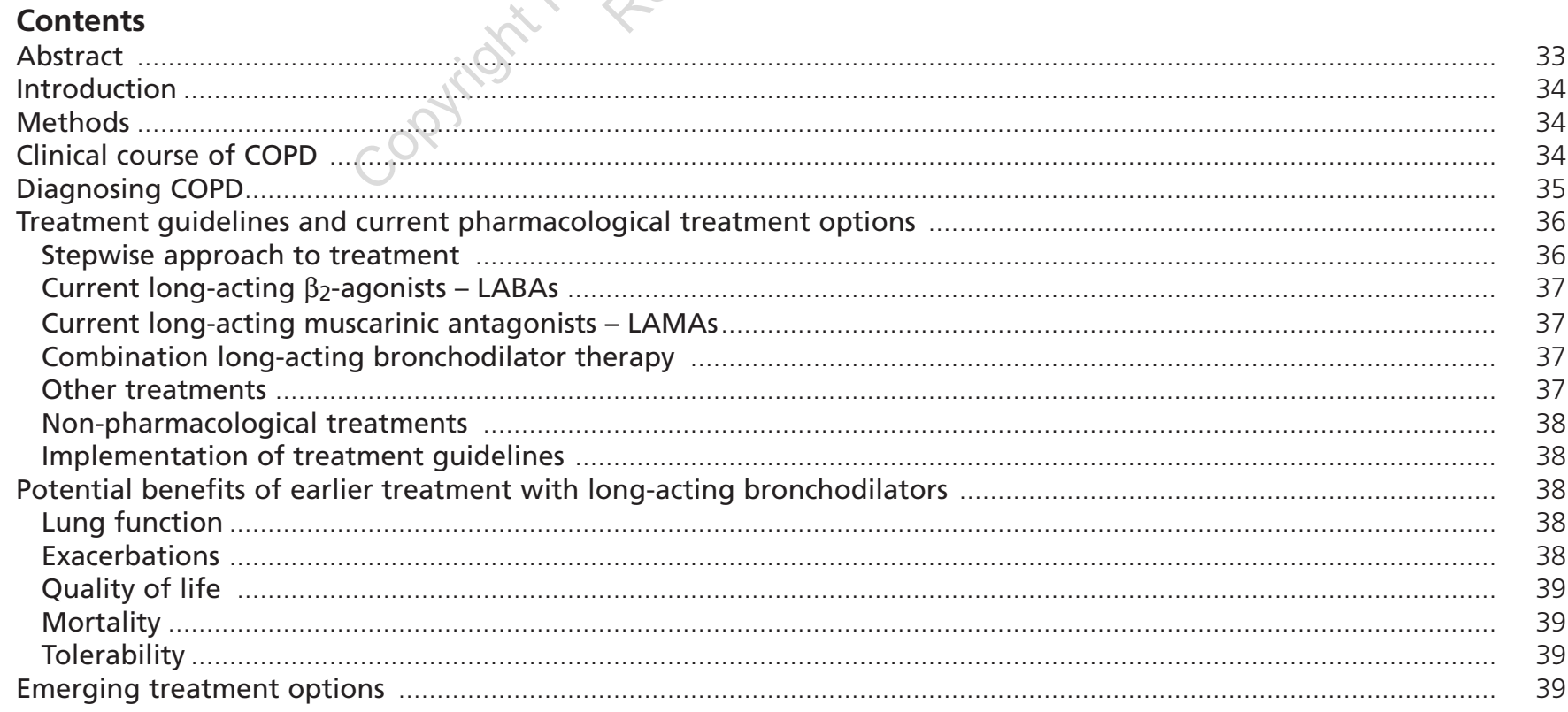

* Corresponding author: Dr Rupert Jones, Primary Care, Peninsula Medical School, 1 Davy Road, Plymouth, UK Tel: +44 1752764293 Fax: +44 1752764259 E-mail: rupert.jones@pms.ac.uk 
Indacaterol

Roflumilast

Other emerging treatments

\section{Introduction}

Chronic obstructive pulmonary disease (COPD) is a respiratory disease characterised by a decline in lung function over time and progressive impairment in quality of life (QoL). The disease has relatively high prevalence rates worldwide $(5-13 \%),{ }^{1-4}$ and is mainly caused by inhalation of noxious substances, predominantly cigarette smoke in the Western world, but also by indoor air pollution, particularly in developing countries. ${ }^{5}$ While smoking rates are declining in developed countries, they are increasing in developing countries; therefore, the prevalence of COPD is predicted to continue to rise as current and future smokers develop the disease. ${ }^{6}$

COPD is associated with high mortality and morbidity rates and a high economic and social burden, mainly due to the requirement for substantial and ongoing medical support. ${ }^{7.8}$ COPD is the fourth leading cause of death worldwide and is projected to be the third leading cause by 2030. ${ }^{9}$ However, COPD kills more patients every year than other high-profile chronic diseases such as diabetes. ${ }^{10}$ Despite the availability of both national and international guidelines, COPD remains substantially under-diagnosed and under-treated and is rarely regarded as a high priority health issue.

There is no cure for COPD. Smoking cessation is the single most effective intervention for reducing the risk of developing COPD and slowing its progression. 11-13 Management of COPD requires adoption of healthy behaviours and long-term pharmacotherapy to maintain QoL and minimise disease burden. Recent evidence indicates that initiating maintenance therapy with long-acting bronchodilator treatment at the early stages of COPD, when symptoms are more than intermittent, may have a significant impact on reducing the impact of the disease..$^{14-16}$

This article will discuss the optimal diagnosis and long-term pharmacological management of COPD, based on recent data for current and emerging treatment options.

\section{Methods}

The studies examined for this review were identified by a structured literature search conducted in December 2009. The search terms: "COPD" AND "diagnosis, spirometry", "burden, prevalence", "asthma, difference", "early treatment", "maintenance treatment", "treatment guidelines", "GOLD stage", "primary care", "exacerbation", "smoking cessation", "long-acting bronchodilator", "inhaled corticosteroid", "longacting beta agonist", "anticholinergic", "muscarinic antagonist" and names of drugs approved for COPD were used in PubMed. Searches were limited to human studies published in English. References included in this article also include studies cited within papers that were identified by the PubMed search. For evidence regarding the long-term benefits of long-acting bronchodilators, we restricted our search to studies with a duration of three years or more. Guideline information was derived principally from the Global Initiative for chronic Obstructive Lung Disease [GOLD]), as these are internationallyrecognised guidelines on which local guidelines are generally based. With respect to emerging drug treatments, this review focuses on the newest agents that have been submitted to authorities for approval: indacaterol and roflumilast. Evidence on these agents included recent publications (identified from PubMed) and American Thoracic Society and European Respiratory Society annual meeting abstracts (identified through online abstract search databases, 2007-2009). Other emerging therapies were identified through searches of pharmaceutical companies' websites.

\section{Clinical course of COPD}

GOLD defines COPD as a disease state "characterized by airflow limitation that is not fully reversible. The airflow limitation is usually both progressive and associated with an abnormal inflammatory response of the lungs to noxious particles or gases". ${ }^{5}$ Significant extra-pulmonary effects and co-morbidities also contribute to the severity of the disease.

The clinical course of COPD is usually progressive, as lung function declines over time. ${ }^{17}$ COPD typically manifests as cough, increased sputum production and dyspnoea (breathlessness) on exertion that leads to reduced activity, deconditioning of the muscles and further inactivity. ${ }^{5,18}$ As the symptoms worsen, QoL is impaired and sleep may be disturbed. Patients become unable to carry out everyday activities, including work and participating in social activities, leading to reduced social interaction. Anxiety and depression may emerge as the patient becomes increasingly isolated and physically disabled by their disease. Exacerbations, defined as acute onset of sustained worsening of symptoms requiring additional medical attention, ${ }^{19}$ become more likely as the disease progresses.

Contrary to the Fletcher-Peto diagram, in which decline in lung function gains pace as the disease advances (Figure 1A), recent studies have suggested that forced expiratory volume in one second $\left(\mathrm{FEV}_{1}\right)$ decline may in fact be greater during earlier rather than later stages of disease. ${ }^{15,16,20}$ We hypothesise that the curve based on these new data presents a very different picture 
Figure 1. A. Effects of smoking and smoking cessation on decline in lung function among adults with COPD (FletcherPeto curve) reproduced with permission. ${ }^{17}$ B. Modified Fletcher-Peto curve redrawn by the authors to incorporate findings of recent advances in the natural history of COPD including FEV 1 decline data from the UPLIFT ${ }^{\oplus}$ study demonstrating greater annual rate of $F_{E V_{1}}$ decline during early stages of disease.

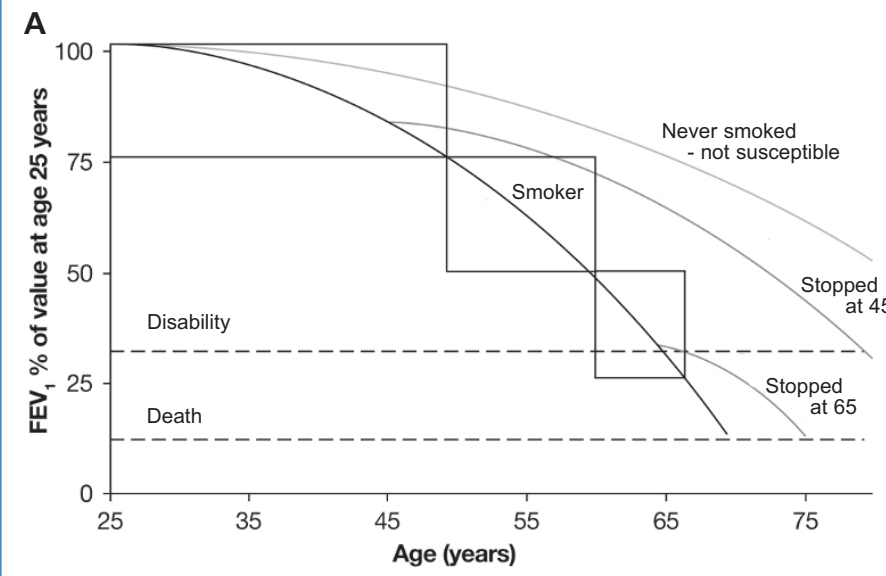

The Fletcher-Peto curve has been the mainstay of understanding regarding the natural history and progression of COPD. ${ }^{17}$ The curve illustrates the relationship between long-term cigarette smoking, decline in lung function ( $\left.\mathrm{FEV}_{1}\right)$ and life expectancy, and suggests slower decline in lung function during the earlier stages of the disease. However, not all patients will follow the same clinical course outlined in the Fletcher-Peto curve, and clinical factors other than airflow limitation that are relevant to COPD natural history (e.g. cough, dyspnoea and QoL measures) remain undefined within the curve.
B

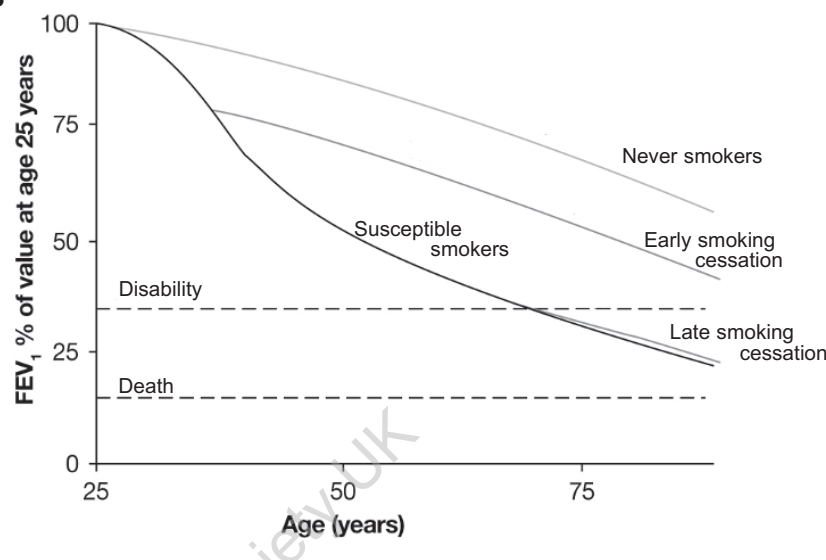

For never smokers the original data for the Fletcher-Peto curve was based on male workers aged 35-59 years, followed for 8 years. ${ }^{17}$ The modified curve has been redrawn by the authors to take into account data from the Framingham study in which healthy non-smokers aged 13-80 years were followed for 26 years with standardised spirometry. ${ }^{137}$ For susceptible smokers the shape of the curve was derived from the decline in lung function from various large trials that showed a faster decline in GOLD stage I-II than stage III-IV groups. . $^{15,16,20}$ from the original curve on which our current understanding of COPD has been based (Figure 1B). The effect of smoking cessation in mild to moderate COPD (GOLD stage I-II) is based on the results of several studies, ${ }^{13}$ including the Lung Health study, ${ }^{21}$ which showed that early smoking cessation is associated with reduced decline in lung function. Few studies have examined the effect of smoking cessation in late stage COPD. The decline in lung function in GOLD stage IV patients from the trials detailed above was similar to that seen in non-smokers. ${ }^{13}$ Although further data are needed to confirm this hypothesis, the implication of initial accelerated decline in lung function is that early detection is critical to facilitate lifestyle modification and initiation of pharmacologic and non-pharmacologic interventions as judged to be clinically relevant - a point not emphasised in the original Fletcher-Peto curve. Such interventions could slow the functional decline, preserve lung function and maintain QoL for patients with COPD. Indeed, diagnosis of airflow limitation and repeated spirometry and smoking cessation support can motivate individuals to modify their smoking habits, although a confrontational approach has recently been shown to be associated with a high failure rate, illustrating the complex nature of smoking cessation interventions. $^{25-28}$

\section{Diagnosing COPD}

COPD is described by GOLD as "a preventable and treatable disease ${ }^{\prime 5}$ and there is increasing prevalence of the disease among younger individuals, most likely as a consequence of increasing smoking rates in developing countries. Many patients with COPD remain undiagnosed (and therefore untreated), or are diagnosed in a late stage of the disease, even though they are smokers or have a smoking history and are therefore at high risk for developing COPD. ${ }^{29-30}$

A range of factors contribute to the under-diagnosis and misdiagnosis of COPD (see Table 1). Under-diagnosis and misdiagnosis of COPD can mean that patients are untreated, or they receive inappropriate treatment, leading to sub-optimal outcomes. ${ }^{25,26}$ Over-diagnosis is also a potential problem in primary care; the current guideline-recommended cut-off point of $\mathrm{FEV}_{1} /$ forced vital capacity (FVC) $<0.70$ has been associated with substantial over-diagnosis in older individuals. ${ }^{31}$

COPD can often be misdiagnosed as asthma. Although both are chronic inflammatory diseases that cause airflow limitation and bronchoconstriction, COPD and asthma are two distinct conditions in terms of age, the underlying airway inflammation, disease onset, frequency of symptoms and reversibility of airway obstruction..$^{32-36}$ Cholinergic tone is the major reversible component of COPD but not asthma. ${ }^{37}$ These fundamental differences mean that the approaches to treating and managing these two respiratory diseases differ.

GOLD treatment guidelines state that, "a clinical diagnosis of COPD should be considered in any patient over 40 years 


\begin{tabular}{|c|c|c|}
\hline & Reasons & Potential solutions \\
\hline \multirow[t]{5}{*}{$\begin{array}{l}\text { Under-diagnosis } \\
\text { of COPD }\end{array}$} & $\begin{array}{l}\text { Physician lack of awareness of symptoms and risk } \\
\text { factors for COPD }\end{array}$ & $\begin{array}{l}\text { Encourage documentation of smoking cessation. } \\
\text { Consider screening for COPD (spirometry) in smokers and/or patients } \\
\text { with cough and/or dyspnoea on mild exertion }\end{array}$ \\
\hline & Physician perception that COPD is self-inflicted & $\begin{array}{l}\text { Increase education of physicians to the nature of smoking - defined by } \\
\text { WHO as a chronic disease }\end{array}$ \\
\hline & $\begin{array}{l}\text { Underuse of spirometry as diagnostic tool in primary } \\
\text { care }\end{array}$ & $\begin{array}{l}\text { Increase availability of spirometers in general practices and/or increase } \\
\text { training on spirometry use }\end{array}$ \\
\hline & $\begin{array}{l}\text { Patient lack of awareness of symptoms and risk } \\
\text { factors for COPD and delayed seeking of medical } \\
\text { advice, sometimes until exacerbations occur }\end{array}$ & $\begin{array}{l}\text { Consider asking simple questions about symptoms and general QOL } \\
\text { during patient visits to help identify COPD }\end{array}$ \\
\hline & $\begin{array}{l}\text { Smokers consider cough and breathlessness as } \\
\text { "normal" with passing years }\end{array}$ & $\begin{array}{l}\text { Encourage documentation of smoking status and consider screening for } \\
\text { COPD (spirometry) }\end{array}$ \\
\hline \multirow[t]{2}{*}{$\begin{array}{l}\text { Misdiagnosis of } \\
\text { COPD }\end{array}$} & $\begin{array}{l}\text { Inaccurate use of spirometry as screening and } \\
\text { diagnostic tool }\end{array}$ & Increase staff training on spirometry use \\
\hline & Confusion between COPD and asthma & $\begin{array}{l}\text { Consider differences in presentation and symptoms between COPD and } \\
\text { asthma and perform spirometry }\end{array}$ \\
\hline \multirow{3}{*}{$\begin{array}{l}\text { Under-treatment } \\
\text { of COPD }\end{array}$} & COPD not diagnosed & See 'Under-diagnosis of COPD' above \\
\hline & COPD misdiagnosed & See 'Misdiagnosis of COPD' above \\
\hline & $\begin{array}{l}\text { Patients have been diagnosed with COPD and are } \\
\text { receiving treatment that is sub-optimal based on the } \\
\text { COPD disease severity }\end{array}$ & $\begin{array}{l}\text { Consider re-evaluation of current treatment and addition of long-acting } \\
\text { bronchodilators (in mild-moderate disease) or other treatments (e.g. } \\
\text { inhaled corticosteroids) to long-acting bronchodilators in patients with } \\
\text { frequent exacerbations, according to guidelines }\end{array}$ \\
\hline
\end{tabular}

presenting with dyspnoea, chronic cough or sputum production, and/or history of exposure to risk factors for the disease". ${ }^{5}$ The next step is to conduct a detailed assessment of symptoms through direct questioning and physical examination, with diagnosis and COPD staging being confirmed by spirometric measurements of airflow limitation (primarily FEV 1 and FVC). COPD is classified according to severity of airflow obstruction as mild, moderate, severe or very severe (life-threatening) designated as stage I, II, III or IV, respectively (Figure 2). ${ }^{5}$ As symptoms are often not directly reflective of airflow limitation, clinical evaluation is generally supplemented by a direct evaluation of breathlessness, for example with the Medical Research Council (MRC) dyspnoea scale. ${ }^{38}$ More recently, multidimensional measures such as the DOSE index and the ADO index, have been developed for use in primary care..$^{39,40}$

\section{Treatment guidelines and current pharmacological treatment options}

A number of national and international respiratory societies have developed guidelines for the management of COPD. ${ }^{41-44}$ The GOLD guidelines are internationally recognised and were developed jointly by the National Heart Lung and Blood Institute and World Health Organisation (WHO) to increase awareness about the importance of COPD. ${ }^{5}$ The International Primary Care Respiratory Group (IPCRG) also developed a set of guidelines
Figure 2. The stepwise approach to the management of COPD (GOLD 2009). Reproduced with permission. ${ }^{5}$

\begin{tabular}{|c|c|c|c|}
\hline $\begin{array}{l}\text { I: Mild } \\
\mathrm{FEV}_{1} / \mathrm{FVC}<0.70 \\
\mathrm{FEV}_{1} \geq 80 \% \\
\text { predicted }\end{array}$ & $\begin{array}{l}\text { II: Moderate } \\
\mathrm{FEV}_{1} / \mathrm{FVC}<0.70 \\
50 \% \leq \mathrm{FEV}_{1}<80 \% \\
\text { predicted }\end{array}$ & $\begin{array}{l}\text { III: Severe } \\
\mathrm{FEV}_{1} / \mathrm{FVC}<0.70 \\
30 \% \leq \mathrm{FEV}_{1}<50 \% \\
\text { predicted }\end{array}$ & $\begin{array}{l}\text { III: Very severe } \\
\mathrm{FEV}_{1 / \mathrm{FVC}}<0.70 \\
\mathrm{FEV} / 1<30 \% \text { predicted, or } \\
\mathrm{FEV} 1<50 \% \text { predicted } \\
\text { plus chronic respiratory } \\
\text { failure }\end{array}$ \\
\hline \multicolumn{4}{|c|}{$\begin{array}{l}\text { Active reduction of risk factor(s); influenza vaccination } \\
\text { Add short-acting bronchodilator (when nieeded) }\end{array}$} \\
\hline \multirow{4}{*}{$\begin{array}{l}\text { Author comments } \\
\text { Patient may not be } \\
\text { aware their lung } \\
\text { function is abnormal }\end{array}$} & \multicolumn{2}{|c|}{$\begin{array}{l}\text { Add regular treatment with one or more Ic } \\
\text { (when needed); adid rehabilitation }\end{array}$} & ng-acting bronchodilators \\
\hline & \multirow[b]{3}{*}{$\begin{array}{l}\text { Symptoms usually } \\
\text { progress at this } \\
\text { stage, with shortness } \\
\text { of breath developing } \\
\text { on exertion }\end{array}$} & $\begin{array}{l}\text { Add inhaled glucoch } \\
\text { exacerbations }\end{array}$ & prticosteroids if repeated \\
\hline & & \multirow[b]{2}{*}{$\begin{array}{l}\text { Shortness of breath } \\
\text { typically worsens at this } \\
\text { stage and limitits daily } \\
\text { activites. Exacerbation } \\
\text { begin to be seen at this } \\
\text { stage }\end{array}$} & $\begin{array}{l}\text { Add long-term oxygen if } \\
\text { chronic respiratory failure. } \\
\text { Consider surgical } \\
\text { treatment }\end{array}$ \\
\hline & & & $\begin{array}{l}\text { Quality of life is appreciably } \\
\text { impaired and exacerbations } \\
\text { may be life-threatening }\end{array}$ \\
\hline \multicolumn{4}{|c|}{$\begin{array}{l}\text { GOLD, Global initiative for chronic Obstructive Lung Disease; FEV }{ }_{1} \text {, forced } \\
\text { expiratory volume in } 1 \mathrm{~s} \text {; FVC, forced vital capacity. }\end{array}$} \\
\hline
\end{tabular}

based on GOLD recommendations but with the aim of being more applicable to the primary care physician. ${ }^{45,46}$

\section{Stepwise approach to treatment}

Current guidelines are in broad agreement that COPD treatment should follow a stepwise approach, depending on disease severity (Figure 2). ${ }^{5}$ Initially, active risk reduction (e.g. smoking cessation and influenza vaccination) should be pursued with the addition of short-acting bronchodilators as- 


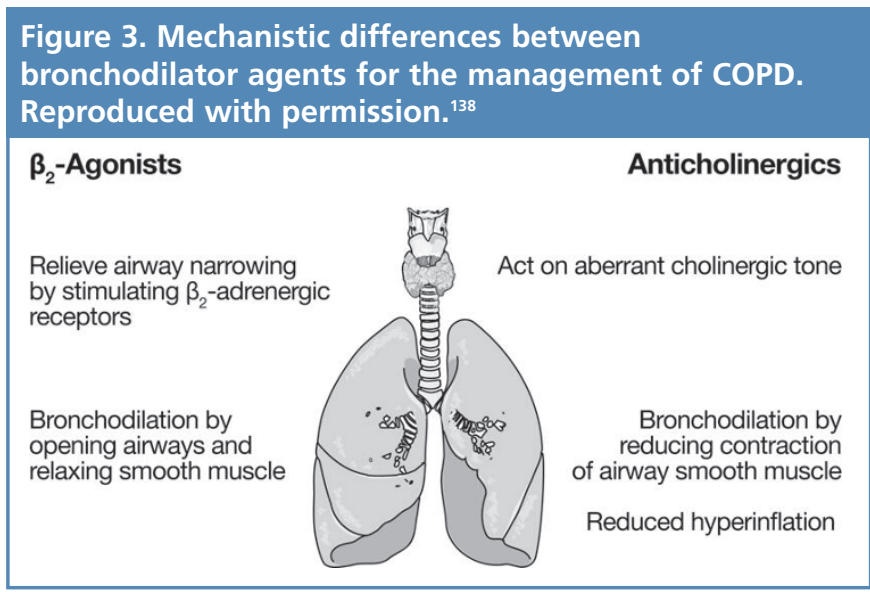

needed. As the disease progresses and lung function declines, regular (maintenance) treatment with one or more longacting bronchodilators, such as a long-acting muscarinic antagonist (LAMA; also known as a long-acting anticholinergic) or long-acting $\beta_{2}$-agonist (LABA), should be introduced. These agents have been shown to relieve symptoms, increase exercise capacity, improve QoL and reduce exacerbations to a greater extent than short-acting bronchodilators. ${ }^{5,47,48}$ Today, they are the foundation treatment for this disease.

The bronchodilatory effects of LABAs and LAMAs are achieved through different mechanisms (Figure 3). While LABAs exert their bronchodilatory effect by stimulating $\beta_{2}$-adrenergic receptors in airway smooth muscle, LAMAs act by reducing the contraction of airway smooth muscle via their inhibition of muscarinic receptors, thus acting on cholinergic tone - an underlying physiological mechanism contributing to bronchoconstriction in COPD. ${ }^{49}$

\section{Current long-acting $\beta_{2}$-agonists - LABAs}

The LABAs salmeterol and formoterol are formulated for twice-daily dosing. These agents have been shown to reduce the need for rescue medication, improve symptoms and patient-related outcomes, and have a favourable safety profile. $^{50-53}$ Formoterol has a faster onset of action than salmeterol, ${ }^{54,55}$ which may be relevant to some patients, especially for morning symptoms. The once-daily LABA indacaterol was approved in Europe in late 2009 for the treatment of COPD, and is discussed in the section "Emerging treatment options" below.

Current long-acting muscarinic antagonists - LAMAs Tiotropium is the only LAMA currently licensed for use in COPD; it improves patient-centred outcomes and has a favourable safety profile. Tiotropium has been formulated for once-daily dosing, providing 24-hour bronchodilation, and is generally recommended for the treatment of all symptomatic patients requiring maintenance treatment. The clinical database for this agent has confirmed the efficacy profile, including symptom improvement, decreased hyperinflation, increased exercise tolerance, reduced dyspnoea, reduced frequency/delayed onset of exacerbations and improved QoL.56-63

Which long-acting bronchodilator should be started first in maintenance therapy? There has been debate as to whether a LABA or a LAMA should be employed first in COPD. International and national guidelines vary; some, such as GOLD ${ }^{5}$ and the National Institute for Health and Clinical Excellence (NICE), ${ }^{44}$ make no clear recommendations either way, but the Swedish ${ }^{43}$ and Canadian ${ }^{42}$ guidelines suggest a LAMA prior to a LABA.

\section{Combination long-acting bronchodilator therapy}

The addition of a LABA to a LAMA (combination therapy) has been shown to be more effective than either agent alone, without increased side effects, ${ }^{59,63,64}$ and is now included as an option for patients who fail with long-acting bronchodilator monotherapy in the current GOLD guidelines. ${ }^{5}$

The use of inhaled corticosteroids (ICS), e.g. fluticasone or budesonide, is not recommended as monotherapy in COPD management; however, ICS agents may have complementary effects when added to a LABA. ${ }^{14,65,66}$ Adding ICS to a LABA is usually recommended for patients with severe or very severe COPD who have repeated exacerbations. ${ }^{5}$ Whilst ICS treatment may not suppress the deterioration of respiratory function or reduce mortality, 67,68 it has been shown to reduce exacerbation frequency and may provide improvements in QoL when combined with LABA therapy. ${ }^{65,66}$ Nevertheless, caution may be required in some patients, since fluticasone has been associated with an increased risk of pneumonia ${ }^{14,61,68-73}$ - an effect that has not been demonstrated with budesonide. ${ }^{74}$

Triple therapy with a LAMA plus a LABA and an ICS may have further clinical benefits in patients with severe COPD. . $5-78^{-7}$ Tiotropium plus salmeterol and fluticasone produced greater improvements in bronchodilation, as well as improved dyspnoea and rescue medication use, than salmeterol plus fluticasone, or tiotropium alone, in 41 patients with severe COPD..$^{75}$ Similarly, the addition of budesonide plus formoterol to tiotropium improved lung function, reduced daytime and night-time symptoms, and reduced exacerbations. ${ }^{77}$ However, longer-term clinical studies are required to confirm the extent of these benefits and cost considerations may constrain the use of triple therapy within the primary care setting.

\section{Other treatments}

A number of other agents are used in the management of COPD, including mucolytics and xanthines such as theophylline.

The use of mucolytics in maintenance therapy for COPD remains controversial. Overall the benefits of therapy appear to be small, although patients with particularly viscous sputum may benefit from long-term therapy. ${ }^{79} \mathrm{GOLD}$ guidelines do not currently recommend the widespread use of these agents. ${ }^{5}$ 
Oral low-dose theophylline can reduce exacerbation rates in COPD patients but offers minimal benefits in terms of lung function. ${ }^{80}$ While high-dose theophylline is an effective bronchodilator, long-acting bronchodilators are preferred because of toxicities associated with high-dose theophylline such as headache, insomnia, nausea and heartburn and potentially life-threatening atrial and ventricular arrhythmias and grand mal convulsions. ${ }^{5}$

\section{Non-pharmacological treatments}

A range of non-pharmacologic treatments are available, some of which are fundamental to the management of COPD. These include exercise, education, pulmonary rehabilitation and management of co-morbidities such as anxiety and depression. Non-pharmacological treatments are outside the scope of this review.

\section{Implementation of treatment guidelines}

Implementation of treatment guidelines is poor and there appear to be major gaps in knowledge among physicians regarding treatment guidelines for the management of COPD, leading to the inappropriate or sub-optimal treatment of COPD patients in the primary care setting..$^{81-84}$

For example, LABAs are often not prescribed in patients with moderate or severe disease, despite their recommendation in treatment guidelines. In patients with mild disease, incorrect prescription of LABA plus ICS combinations is common in primary ${ }^{83}$ and secondary ${ }^{84}$ care. In the Understanding Potential Long-term Impacts on Function with Tiotropium (UPLIFT ${ }^{\oplus}$ ) trial, approximately $60 \%$ and $45 \%$ of GOLD stage II patients were receiving either ICS or LABA plus ICS combination, respectively, at baseline, despite guidelines recommending that only patients with GOLD stage III or IV should be treated with these agents. 15.85 In Finland, a 10-year national programme resulted in successful implementation of asthma treatment guidelines, leading to improved patient care and outcomes, and a reduction in economic burden. ${ }^{86}$ Application of similar strategies to COPD care may have the potential to generate equally successful results.

\section{Potential benefits of earlier treatment with long-acting bronchodilators}

During the early stages of disease, breathlessness may occur only on exertion. However, hyperinflation due to air trapping causes the lungs of patients with COPD to operate at volumes near to total capacity leaving little additional capacity for increased respiration during increased activity (Figure 4). ${ }^{87}$ Early interventions with inhaled bronchodilators to relieve breathlessness may maintain or improve the capacity for physical activity and thereby slow the progression of symptoms. ${ }^{87}$

Results from the large, long-term (3 years) Towards a Revolution in COPD Health (TORCH) $)^{14,88}$ and UPLIFT ${ }^{\oplus 85}$ (4 years) studies have demonstrated the benefits of long-acting
Figure 4. Lung volume and respiratory capacity in healthy lungs and COPD. Reproduced with permission. ${ }^{87}$

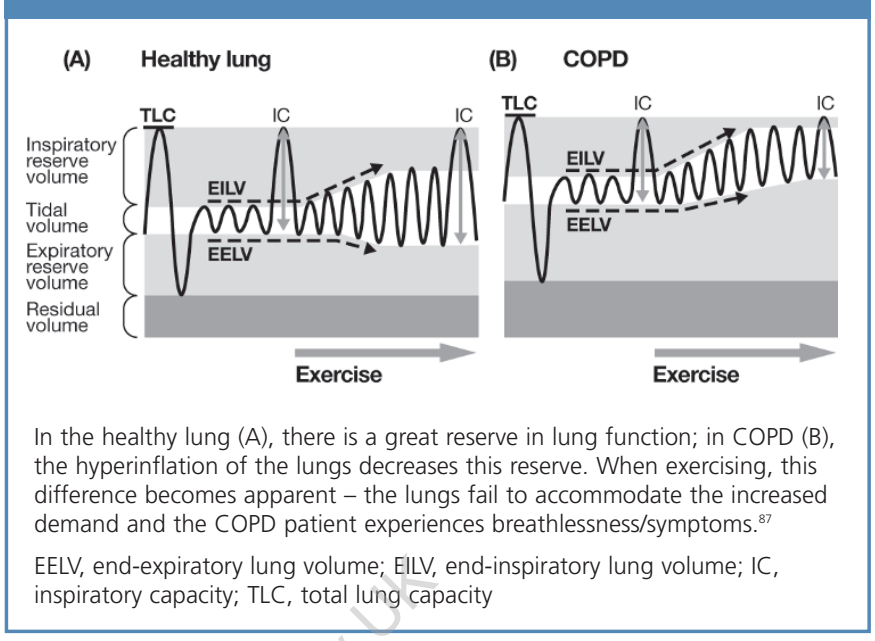

bronchodilator treatment in COPD patients in terms of improved lung function, reduced exacerbations and improved QoL. In addition to clinical improvements in the overall patient cohorts in these studies, patients with early stage COPD derived clinical benefits, as summarised below. When considering these results it should be noted that direct comparisons between the studies should be avoided given the differences in study design (notably permitted respiratory medications), inclusion criteria and outcome measures. ${ }^{89}$

\section{Lung function}

Post-hoc analyses of patients in the earlier disease stages (GOLD stage II) have shown an improvement in rate of FEV 1 decline with active bronchodilator therapy versus control in both TORCH (salmeterol plus fluticasone or either agent alone versus placebo) and UPLIFT $^{\circledR}$ (tiotropium versus placebo) (Figure 5A). . $1,16^{\text {Two further sub-analyses of UPLIFT }}{ }^{\circledR}$ have demonstrated lung function improvements with tiotropium in other categories of patients who may be considered as having earlier disease: younger patients aged $<50$ years; ${ }^{90}$ and patients who were not receiving maintenance therapy at the start of the study (i.e. who were "maintenance naïve"). ${ }^{91}$

\section{Exacerbations}

In GOLD stage II patients in TORCH, combination therapy (salmeterol plus fluticasone) reduced the annual rate of exacerbations compared with placebo (Figure 5B). ${ }^{16}$ In UPLIFT ${ }^{\oplus}$, tiotropium significantly reduced the mean number of exacerbations per patient year versus control in GOLD stage II patients (Figure 5B) and in patients aged $<50$ years. ${ }^{15,90}$ In addition, tiotropium significantly reduced the risk of hospitalisation for exacerbation versus control in GOLD stage II patients $(26 \% \text { reduction, } \mathrm{p}<0.001)^{15}$ and in maintenancenaïve patients (23\% reduction; $p=0.012) .{ }^{91}$ Data on hospitalisations for exacerbations by GOLD stage has not been reported in TORCH. 
Figure 5. Lung function, exacerbations, and quality-of-life outcomes in patients with earlier disease (GOLD stage II) in UPLIFT ${ }^{15}$ and TORCH ${ }^{16}$ trials.

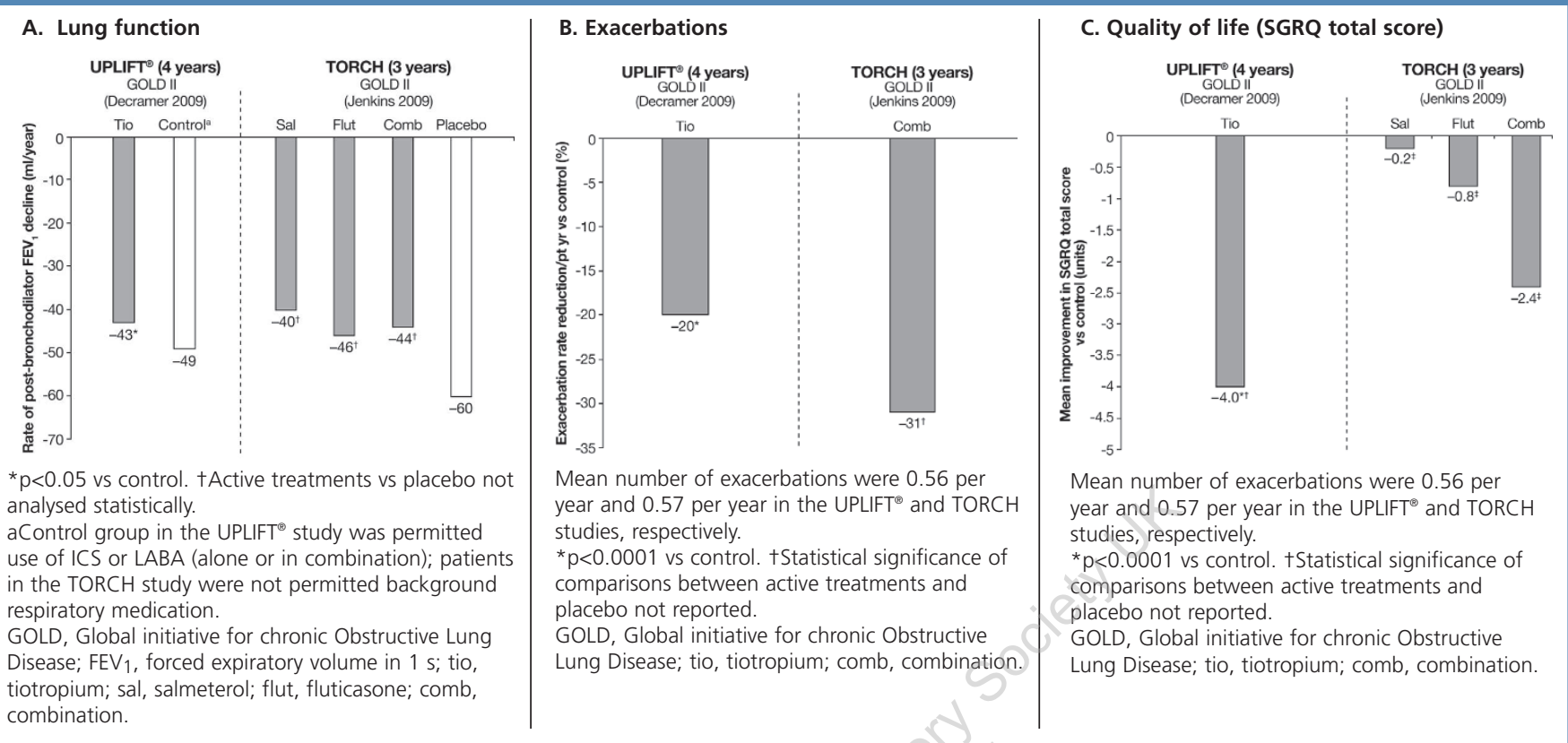

\section{Quality of life}

Health status was measured by the St George's Respiratory Questionnaire (SGRQ) ${ }^{92}$ in the TORCH and UPLIFT ${ }^{\circledR}$ studies. A mean reduction in SGRQ total score of four or more units is defined as being a clinically significant improvement. ${ }^{92}$ In the TORCH sub-analysis by GOLD stage, combination therapy provided greater improvements in health status versus placebo in patients with increasing GOLD stage.$^{16}$ In GOLD stage II patients, again, combination treatment provided the greatest improvements in SGRQ total score (-2.4 units; Figure 5C). For GOLD stage II patients in the UPLIFT' ${ }^{\oplus}$ study, tiotropium improved health status at all time points, with differences in SGRQ total scores ranging between 2.7 and 4.0 units (Figure 5C). ${ }^{15}$ Therefore, clinically significant improvements in health status in GOLD stage II patients were achieved only with tiotropium. These data are derived from sub-analyses (albeit protocoldefined, or prespecified, in the UPLIFT ${ }^{\circledR}$ study), therefore caution is required when interpreting analyses that are made from such a dataset. The results should be confirmed in adequately powered and designed studies.

\section{Mortality}

Mortality was reduced with active bronchodilator therapy in patients with early stage disease in both the TORCH and UPLIFT ${ }^{\oplus}$ studies. In TORCH, combination treatment significantly reduced the risk of death by $33 \%$ in GOLD stage II patients compared with placebo. ${ }^{16}$ In UPLIFT ${ }^{\oplus}$, reduced risks of death from lower respiratory conditions and all causes were seen in GOLD stage II patients compared with control; however, differences between the treatment groups were not significant. ${ }^{15}$

\section{Tolerability}

As with all medications, tolerability is a key factor that influences adherence and treatment discontinuation. Approximately $90 \%$ of patients experienced an adverse event in the TORCH and UPLIFT ${ }^{\circledR}$ studies, with the most common events being due to respiratory causes (predominantly COPD exacerbations). Adverse events noted in these studies were generally consistent with those commonly associated with the drug classes given; tiotropium was associated with an increased incidence of dry mouth and constipation, ${ }^{85}$ and fluticasone-containing treatments in TORCH were associated with an increased probability of pneumonia..$^{14,73}$

\section{Emerging treatment options}

Current efforts appear to be focused on the development of new drugs or combinations of existing agents, notably the development of new once-daily LAMAs and LABAs, combinations of LAMA plus LABA and once-daily LABA plus ICS combinations. ${ }^{93-103}$ Two agents that have recently received approval within the last few months to treat COPD are indacaterol and roflumilast.

\section{Indacaterol}

The European Commission (EC) approved indacaterol as maintenance bronchodilator treatment of COPD in December 2009, and approval is pending in the USA. It is the first oncedaily LABA. Compared to placebo in dose-ranging studies, it has been shown to improve lung function, QoL and reduce exacerbations. ${ }^{104}$ Two phase III studies have compared the efficacy and safety of indacaterol versus the once-daily LAMA, 
tiotropium, and versus the twice-daily LABA, formoterol. To date, the data have been published in abstract form only.

In the 26-week Indacaterol versus Tiotropium to Help Achieve New COPD Treatment Excellence (INHANCE) study, indacaterol provided significant improvements in $\mathrm{FEV}_{1}, \mathrm{QoL}$, dyspnoea and use of rescue medication compared with placebo. ${ }^{105-108}$ The lung function improvements were at least as good as tiotropium, but this was an open-label study and comparisons between the effects of the drugs are difficult to interpret.

In a 52-week study, significant improvements in lung function were seen with indacaterol compared with formoterol and placebo. ${ }^{109}$ Significant improvements in QoL, symptom improvement and dyspnoea were observed with both active treatments compared with placebo, with greatest improvements being achieved with indacaterol. ${ }^{110-112}$

In both trials, a similar incidence of adverse events was reported in the active treatment groups..$^{113,114}$

Indacaterol could become an important once-daily LABA therapy for maintenance treatment of COPD. However, further studies are required before firm conclusions can be made. In addition, indacaterol currently lacks data beyond one year, so its long-term impact on COPD remains unclear.

\section{Roflumilast}

Phosphodiesterase-4 (PDE4) inhibitors have anti-inflammatory activity that specifically targets cells commonly linked with airways inflammation and pathogenesis of disease, and have been shown to reduce airway inflammation in preclinical and clinical studies. ${ }^{115}$ Theophylline is an established PDE4 inhibitor; however, its non-selective inhibitory action and the range of other pharmacological actions mean that theophylline has been relegated to second- or third-line treatment of COPD. Roflumilast is another once-daily, oral PDE4 inhibitor. However, the selective mode of action of roflumilast means that it is regarded as the first in its class. In April 2010, roflumilast received initial authorisation in Europe as add-on therapy to bronchodilator treatment for severe COPD ( $F E V_{1}<50 \%$ predicted) in patients with a history of exacerbations. ${ }^{116}$

Roflumilast has been shown to improve lung function compared with placebo, although the improvements are moderate (pre-bronchodilator increase in $\mathrm{FEV}_{1}$ in the order of 48 $\mathrm{mL}^{117}$ ) compared with inhaled bronchodilators such as tiotropium or salmeterol (pre-bronchodilator increase in $\mathrm{FEV}_{1}$ in excess of $100 \mathrm{~mL}^{118,119}$ ). Roflumilast was also shown to reduce exacerbations and the requirement for anti-inflammatory/antiinfective medications, and to improve QoL measures..171,120 Other studies have shown significant improvements in pre- and postbronchodilator $\mathrm{FEV}_{1}$ versus placebo when roflumilast was added to salmeterol or to tiotropium. ${ }^{121}$ Adding roflumilast to salmeterol was associated with reduced exacerbations, although no significant improvements were seen in this regard when roflumilast was added to tiotropium. Conversely, roflumilast appeared to improve dyspnoea and rescue medication when added to tiotropium, but not when added to salmeterol. ${ }^{121}$

Nausea, diarrhoea and weight loss are common side effects of PDE4 inhibitors, which may limit the use of roflumilast in some COPD patients. Nevertheless, roflumilast is potentially a valid alternative to concomitant ICS, and is an interesting new development as an add-on therapy to long-acting bronchodilators.

\section{Other emerging treatments}

Several other investigational products for the treatment of COPD are currently in development and are expected to enter the market over the next few years. These include the longacting muscarinic antagonist aclidinium (estimated 2012 launch), ${ }^{122-124}$ new LABA plus ICS combinations, and triple combinations of a LAMA plus LABA plus ICS. ${ }^{77,78,125}$

\section{Review of optimal maintenance treatment for COPD}

Maintenance therapy for COPD can be defined as medication taken regularly when symptoms are more than just intermittent, to improve symptoms and long term outcomes. Bronchodilator therapy is critical in the treatment of early COPD. The GOLD guidelines advocate early diagnosis and treatment implementation, and recommend a policy of identifying patients at high risk of COPD followed by "watchful surveillance". ${ }^{5}$ Subanalysis data from the UPLIFT ${ }^{\oplus}$ and TORCH studies show that initiating maintenance treatment at early stages in the disease, when there is an opportunity to alter progression of the disease and maximise patient benefit, can be more impactful than at later stages of the disease. Data from studies designed to examine these benefits in patient cohorts with early-stage disease are now needed to support clinical decision-making and initiation of maintenance treatment early in the disease process.

The long-acting bronchodilators tiotropium, salmeterol and formoterol have been evaluated in a broad range of COPD patients, many of whom were taking additional medications. For instance, the design of the UPLIFT ${ }^{\oplus}$ study permitted the continued use of baseline respiratory medications in addition to tiotropium, and therefore closely represented standards of care and types of patients seen in everyday practice. In addition, there are few interactions between long-acting bronchodilators and other medications used to treat co-morbidities (common in COPD patients).

Despite the GOLD guideline advocacy of early diagnosis and treatment, and clinical evidence for the long-term benefit of maintenance treatment with bronchodilators, the identification of patients with COPD has proved difficult in general practice. There is a requirement for improved recognition of patient profiles, COPD risk factors, diagnostic criteria, and treatment 
Table 2. Key factors influencing non-adherence to prescribed therapies for COPD.

\begin{tabular}{|c|c|}
\hline Treatment-related & Patient-related \\
\hline $\begin{array}{l}\text { - } \quad \text { Duration of treatment } \\
\text { - } \quad \text { Purpose of treatment (preventive or symptomatic) } \\
\text { - } \quad \text { Cost of action (delayed, immediate) } \\
\text { - Complexity (multi-treatments or multi-dose) }\end{array}$ & $\begin{array}{l}\text { - } \quad \text { Motivation (concern about health, willingness to seek medical advice, intention to comply) } \\
\text { - } \\
\text { - Acceptance and understanding of illness (severity, prognosis) } \\
\text { - } \text { absence of symptoms) } \\
\text { - } \quad \text { Concerstanding treatment instructions (dosing, inhaler technique) } \\
\text { - } \text { Age (cognition) } \\
\text { - } \quad \text { Satisidence in the physician/involvement in care plan } \\
\text { - } \quad \text { Economith treatment (lack of effect/perceived benefit) } \\
\text { - } \quad \text { Access to health care and medications } \\
\text { Psychogical factors (anxiety, depression) }\end{array}$ \\
\hline
\end{tabular}

pathways. While COPD is primarily a disease of older people, physicians should be aware that COPD can affect smokers and non-smokers in their 30s and 40s..$^{90,126,127}$ Similarly, patients need to be alerted to the factors that may increase their risk of developing COPD and to recognise particular symptoms, to prompt them to seek medical attention at an earlier stage in the disease process.

A priority in improving COPD diagnosis at an early stage is the increased use and accurate interpretation of spirometry, which continues to be under-used. Moreover, evidence suggests important deficiencies in the interpretation of results. ${ }^{128}$ In many countries, few primary care practices have access to spirometers or have adequately trained staff. Yet, early screening of patients with risk factors and symptoms using spirometry has been shown to yield detection rates of between $18-27 \% .{ }^{28,129}$ In a prospective study of primary care patients aged between 35 and 70 years, screening using spirometry doubled the number of patients identified with obstructive lung disease. ${ }^{130}$ Tools such as the handheld digital PiKo- 6 device, which measures forced expiratory volume in 6 seconds, may help screen patients and identify the need to test lung function using spirometry. ${ }^{131,132}$

Finally, disease management is evolving towards more patient-focused care. An important component of optimal treatment is patient involvement in the development of their care plan. Simple questionnaires are a useful vehicle for increasing patient awareness regarding the implications of their condition and for the physician to gain a fuller understanding of COPD from the patient's perspective with respect to activity limitation, other QoL issues, and requirement for symptomatic relief. The care plan is also an important opportunity to encourage adherence to prescribed treatment, so that patients achieve optimal benefits. Adherence to inhaled bronchodilators is known to be poor and can be influenced by numerous factors (Table 2). ${ }^{133-135}$ Patient education should be viewed as a priority, as improved adherence can reduce the risk of death and hospital admissions for exacerbations. ${ }^{135}$

Identification of patients at risk for, or at an early stage of,
COPD, together with an optimised care plan, has the potential to impact markedly on public health and reduce the social and economic burden of this chronic disease. ${ }^{136}$

\section{Conclusions}

COPD is a chronic disease that is frequently undiagnosed and untreated but increasing in prevalence. Recent data from longterm trials show that long-acting bronchodilator therapy in the earlier stages of disease may alter the clinical course of COPD and improve patients' lung function, symptoms and QoL. Physicians in general practice should strive to identify early-stage COPD patients and begin treatment programmes that include lifestyle changes, and potentially maintenance therapy with long-acting bronchodilators such as the anticholinergic tiotropium or the $\beta_{2}$-agonists salmeterol or formoterol. The use of $\beta_{2}$-agonist plus ICS combination therapy is appropriate for patients with severe COPD, for those with a history of exacerbations, and as an add-on to tiotropium (triple therapy) when necessary for symptom control. Emerging treatments such as indacaterol and roflumilast show promise, although further data are required before their place in the COPD treatment paradigm can be established.

\section{Acknowledgements}

The authors would like to thank Professor Idelle Weisman MD from Pfizer for suggesting the article and for her assistance regarding scientific content, and Natalie Barker and Claire Scarborough from PAREXEL MMS for their assistance in developing the article. The work performed by PAREXEL MMS was funded jointly by Boehringer Ingelheim and Pfizer. The authors are exclusively responsible for direction with respect to the content of the article.

\section{Conflict of interest declarations}

RJ has been paid to take part in educational activities related to COPD for Altana, AstraZeneca, Boehringer Ingelheim (BI), GlaxoSmithKline (GSK), Novartis, Nutricia, Pfizer, TEVA, Tejin and Trinity Chiesi in the last 3 years. RJ is a consultant to the global emPOWER educational programme supported by Pfizer and BI.

$A \varnothing$ has been paid to take part in advisory boards related to COPD for BI, Pfizer and Nycomed. He has spoken at educational meetings financed by GSK, BI and Pfizer in the last 3 years. He is a consultant on the global emPOWER educational programme supported by Pfizer and BI. 


\section{References}

1. Menezes AM, Perez-Padilla R, Hallal PC, et al. Worldwide burden of COPD in highand low-income countries. Part II. Burden of chronic obstructive lung disease in Latin America: the PLATINO study. Int J Tuberc Lung Dis 2008;12(7):709-12.

2. Shahab L, Jarvis MJ, Britton J, West R. Prevalence, diagnosis and relation to tobacco dependence of chronic obstructive pulmonary disease in a nationally representative population sample. Thorax 2006;61(12):1043-7. http://dx.doi.org/10.1136/ thx.2006.064410

3. Buist AS, Vollmer WM, McBurnie MA. Worldwide burden of COPD in high- and low-income countries. Part I. The burden of obstructive lung disease (BOLD) initiative. Int J Tuberc Lung Dis 2008;12(7):703-08.

4. Lopez AD, Shibuya K, Rao C, et al. Chronic obstructive pulmonary disease: current burden and future projections. Eur Respir J 2006;27(2):397-412. http://dx.doi.org/10.1183/09031936.06.00025805

5. Global Initiative for Chronic Obstructive Lung Disease. Global strategy for the diagnosis, management, and prevention of chronic obstructive pulmonary disease. www.goldcopd.com. Accessed January 14, 2010.

6. Mannino DM , Buist AS. Global burden of COPD: risk factors, prevalence, and future trends. Lancet 2007;370(9589):765-73. http://dx.doi.org/10.1016/S01406736(07)61380-4

7. Nielsen R, Johannessen A, Benediktsdottir B, et al. Present and future costs of COPD in Iceland and Norway: results from the BOLD study. Eur Respir J 2009;34(4):850-7. http://dx.doi.org/10.1183/09031936.00166108

8. Sullivan SD, Ramsey SD, Lee TA. The economic burden of COPD. Chest 2000;117:5S-9S. http://dx.doi.org/10.1378/chest.117.2_suppl.5S

9. Mathers $C D$, Loncar D. Projections of global mortality and burden of disease from 2002 to 2030. PLoS Med 2006;3(11):e442 http://dx.doi.org/ 10.1371/journal.pmed.0030442

10. Jemal A, Ward E, Hao $Y$, Thun M. Trends in the leading causes of death in the United States, 1970-2002. JAMA 2005;294(10):1255-9.

11. Camilli AE, Burrows $B$, Knudson RJ, Lyle SK, Lebowitz MD. Longitudinal changes in forced expiratory volume in one second in adults. Effects of smoking and smoking cessation. Am Rev Respir Dis 1987;135(4):794-9.

12. Scanlon PD, Connett JE, Waller LA, et al. Smoking cessation and lung function in mild-to-moderate chronic obstructive pulmonary disease. The Lung Health Study. Am J Respir Crit Care Med 2000;161(2):381-90.

13. Willemse BW, Postma DS, Timens W, ten Hacken NH. The impact of smoking cessation on respiratory symptoms, lung function, airway hyperresponsiveness and inflammation. Eur Respir J 2004;23(3):464-76. http://dx.doi.org/ 10.1183/09031936.04.00012704

14. Calverley PMA, Anderson JA, Celli B, et al. Salmeterol and fluticasone propionate and survival in chronic obstructive pulmonary disease. $N$ Engl J Med 2007;356(8):775-89. http://dx.doi.org/10.1056/NEJMoa063070

15. Decramer M, Celli B, Kesten S, Lystig T, Mehra S, Tashkin DP. Effect of tiotropium on outcomes in patients with moderate chronic obstructive pulmonary disease (UPLIFT): a prespecified subgroup analysis of a randomised controlled trial. Lancet 2009;374(9696):1171-8. http://dx.doi.org/10.1016/S0140-6736(09)61298-8

16. Jenkins $C R$, Jones PW, Calverley PM, et al. Efficacy of salmeterol/fluticasone propionate by GOLD stage of chronic obstructive pulmonary disease: analysis from the randomised, placebo-controlled TORCH study. Respir Res 2009;10:59

17. Fletcher $\mathrm{C}$, Peto R. The natural history of chronic airflow obstruction. Br Med J 1977;1(6077):1645-8

18. Decramer M, Rennard S, Troosters $\mathrm{T}$, et al. COPD as a lung disease with systemic consequences--clinical impact, mechanisms, and potential for early intervention. COPD 2008;5(4):235-56.

19. Burge $S$, Wedzicha JA. COPD exacerbations: definitions and classifications. Eur Respir J Supp/ 2003;41:46s-53s. http://dx.doi.org/10.1183/09031936.03.00078002

20. Beaucage F, Frémault $A$, Janssens W, Pottel H, Decramer M. FEV1 decline in COPD patients according to severity stages. Am J Respir Crit Care Med 2008;177:A401.

21. Anthonisen NR, Connett JE, Kiley JP, et al. Effects of smoking intervention and the use of an inhaled anticholinergic bronchodilator on the rate of decline of FEV1. The Lung Health Study. JAMA 1994;272(19):1497-505.

22. Gorecka D, Bednarek M, Nowinski A, Puscinska E, Goljan-Geremek A, Zielinski J. Diagnosis of airflow limitation combined with smoking cessation advice increases stop-smoking rate. Chest 2003;123:1916-23. http://dx.doi.org/10.1378/ chest.123.6.1916

23. Stratelis G, Molstad S, Jakobsson P, Zetterstrom O. The impact of repeated spirometry and smoking cessation advice on smokers with mild COPD. Scand J Prim Health Care 2006;24:133-139. http://dx.doi.org/10.1080/02813430600819751

24. Kotz D, Wesseling G, Huibers MJ, van Schayck OC. Efficacy of confronting smokers with airflow limitation for smoking cessation. Eur Respir J 2009;33:754-62. http://dx.doi.org/10.1183/09031936.00116308

25. Yawn B, Mannino D, Littlejohn T, et al. Prevalence of COPD among symptomatic patients in a primary care setting. Curr Med Res Opin 2009;25(11):2671-7.

26. Bednarek M, Maciejewski J, Wozniak M, Kuca P, Zielinski J. Prevalence, severity and underdiagnosis of COPD in the primary care setting. Thorax 2008;63(5):402-07. http://dx.doi.org/10.1136/thx.2007.085456

27. Vandevoorde J, Verbanck S, Gijssels L, et al. Early detection of COPD: a case finding study in general practice. Respir Med 2007;101(3):525-30.

28. Tinkelman DG, Price D, Nordyke RJ, Halbert RJ. COPD screening efforts in primary care: what is the yield? Prim Care Resp J 2007;16(1):41-8. http://dx.doi.org/10.3132/pcrj.2007.00009

29. Tinkelman DG, Price DB, Nordyke RJ, Halbert RJ. Misdiagnosis of COPD and asthma in primary care patients 40 years of age and over. J Asthma 2006;43(1):7580. http://dx.doi.org/10.1080/02770900500448738

30. Kesten S, Chapman KR. Physician perceptions and management of COPD. Chest 1993; 104(1):254-8.

31. Schermer TR, Smeele IJ, Thoonen BP, et al. Current clinical guideline definitions of airflow obstruction and COPD overdiagnosis in primary care. Eur Respir $J$ 2008;32:945-52. http://dx.doi.org/10.1183/09031936.00170307

32. Barnes PJ. Mechanisms in COPD. Differences from asthma. Chest 2000;117(2):10S-4S. http://dx.doi.org/10.1378/chest.117.2_suppl.10S

33. Jeffery PK. Comparison of the structural and inflammatory features of COPD and asthma. Giles F Filley lecture. Chest 2000;117(5):251S-60S. http://dx.doi.org/10.1378/chest.117.5_suppl_1.251S

34. Buist AS. Similarities and differences between asthma and chronic obstructive pulmonary disease: treatment and early outcomes. Eur Respir J Supp/ 2003;39:30s5s. http://dx.doi.org/10.1183/09031936.03.00404903

35. Welte T, Groneberg DA. Asthma and COPD. Exp Toxicol Pathol 2006;57 Suppl 2:35-40. http://dx.doi.org/10.1016/j.etp.2006.02.004

36. Chang J , Mosenifar Z. Differentiating COPD from asthma in clinical practice. J Intensive Care Med 2007;22(5):300-09. http://dx.doi.org/10.1177/0885066607304445

37. Brusasco V. Reducing cholinergic constriction: the major reversible mechanism in COPD. Eur Respir Rev 2006;15(99):32-6. http://dx.doi.org/10.1183/ 09059180.00009902

38. Fletcher CM, Elmes PC, Fairbain AS. The significance of respiratory symptoms and diagnosis of chronic bronchitis in working population. BMJ 1959;2:257-66.

39. Jones RC, Donaldson GC, Chavannes $\mathrm{NH}$, et al. Derivation and validation of a composite index of severity in chronic obstructive pulmonary disease: the DOSE Index. Am J Respir Crit Care Med 2009;180(12):1189-95. http://dx.doi.org/10.1164/rccm.200902-02710C

40. Puhan MA, Garcia-Aymerich J, Frey $M$, et al. Expansion of the prognostic assessment of patients with chronic obstructive pulmonary disease: the updated BODE index and the ADO index. Lancet 2009;374:704-11. http://dx.doi.org/10.1016/S0140-6736(09)61301-5

41. Celli BR, MacNee W, and committee members. Standards for the diagnosis and treatment of patients with COPD: a summary of the ATS/ERS position paper. Eur Respir J 2004;23:932-46. http://dx.doi.org/10.1183/09031936.04.00014304

42. O'Donnell DE, Aaron S, Bourbeau J, et al. Canadian Thoracic Society recommendations for management of chronic obstructive pulmonary disease - 
2007 update. Can Respir J 2007; 14 Suppl B:5B-32B.

43. National Board of Health and Welfare. The National Board of Health and Welfare Guidelines for Asthma and COPD 2004 (in Swedish). Socialstyrelsen 2004;

44. National Institute for Clinical Excellence. Chronic obstructive pulmonary disease: management of chronic obstructive pulmonary disease in adults in primary and secondary care. Clinical guideline 12. Thorax 2004;59 (Suppl I):i1-i232

45. Bellamy D, Bouchard J, Henrichsen S, et al. International Primary Care Respiratory Group (IPCRG) Guidelines: management of chronic obstructive pulmonary disease (COPD). Prim Care Resp J 2006;15(1):48-57. http://dx.doi.org/10.1016/ j.pcri.2005.11.003

46. Levy ML, Fletcher M, Price DB, Hausen T, Halbert RJ, Yawn BP. International Primary Care Respiratory Group (IPCRG) Guidelines: diagnosis of respiratory diseases in primary care. Prim Care Resp J 2006;15(1):20-34. http://dx.doi.org/ 10.1016/j.pcrj.2005.10.004

47. Sin DD, McAlister FA, Man SF, Anthonisen NR. Contemporary management of chronic obstructive pulmonary disease: scientific review. JAMA 2003;290(17):2301-12.

48. Tashkin DP, Cooper CB. The role of long-acting bronchodilators in the management of stable COPD. Chest 2004;125(1):249-59. http://dx.doi.org/ 10.1378/chest.125.1.249

49. Vincken W. Bronchodilator treatment of stable COPD: long-acting anticholinergics. Eur Respir Rev 2005;14:23-31. http://dx.doi.org/10.1183/09058180.05.00009403

50. Campbell M, Eliraz A, Johansson G, et al. Formoterol for maintenance and asneeded treatment of chronic obstructive pulmonary disease. Respir Med 2005;99(12):1511-20. http://dx.doi.org/ 10.1016/j.rmed.2005.08.016

51. Derom E, Strandgarden K, Schelfhout V, Borgstrom L, Pauwels R. Lung deposition and efficacy of inhaled formoterol in patients with moderate to severe COPD. Respir Med 2007;101(9):1931-41. http://dx.doi.org/ 10.1016/j.rmed.2007.04.013

52. Mahler DA, Donohue JF, Barbee RA, et al. Efficacy of salmeterol xinafoate in the treatment of COPD. Chest 1999;115(4):957-65. http://dx.doi.org/ 10.1378/chest.115.4.957

53. Ramirez-Venegas A, Ward J, Lentine T, Mahler DA. Salmeterol reduces dyspnea and improves lung function in patients with COPD. Chest 1997;112(2):336-40. http://dx.doi.org/10.1378/chest.112.2.336

54. Cote C, Pearle JL, Sharafkhaneh A, Spangenthal S. Faster onset of action of formoterol versus salmeterol in patients with chronic obstructive pulmonary disease: a multicenter, randomized study. Pulm Pharmacol Ther 2009;22(1):44-9. http://dx.doi.org/10.1016/j.pupt.2008.11.010

55. Kottakis J, Cioppa GD, Creemers J, et al. Faster onset of bronchodilation with formoterol than with salmeterol in patients with stable, moderate to severe COPD: results of a randomized, double-blind clinical study. Can Respir J 2002;9(2):107-15.

56. Briggs DD, Jr., Covelli H, Lapidus R, Bhattycharya S, Kesten S, Cassino C. Improved daytime spirometric efficacy of tiotropium compared with salmeterol in patients with COPD. Pulm Pharmacol Ther 2005;18(6):397-404. http://dx.doi.org/ 10.1016/j.pupt.2005.02.013

57. Brusasco V, Hodder R, Miravitlles M, Korducki L, Towse L, Kesten S. Health outcomes following treatment for six months with once daily tiotropium compared with twice daily salmeterol in patients with COPD. Thorax 2003;58(5):399-404.

58. Casaburi R, Mahler DA, Jones PW, et al. A long-term evaluation of once-daily inhaled tiotropium in chronic obstructive pulmonary disease. Eur Respir J 2002;19:217-24. http://dx.doi.org/10.1183/09031936.02.00269802

59. van Noord JA, Aumann JL, Janssens E, et al. Comparison of tiotropium once daily, formoterol twice daily and both combined once daily in patients with COPD. Eur Respir J 2005;26(2):214-22. http://dx.doi.org/10.1183/09031936.05.00140404

60. Vincken W, van Noord JA, Greefhorst APM, et al. Improved health outcomes in patients with COPD during 1 yr's treatment with tiotropium. Eur Respir J 2002;19:209-16. http://dx.doi.org/10.1183/09031936.02.00238702

61. Wedzicha JA, Calverley PM, Seemungal TA, Hagan G, Ansari Z, Stockley RA. The prevention of chronic obstructive pulmonary disease exacerbations by salmeterol/fluticasone propionate or tiotropium bromide. Am J Respir Crit Care
Med 2008;177(1):19-26.http://dx.doi.org/10.1164/rccm.200707-9730C

62. Decramer M. Tiotropium as essential maintenance therapy in COPD. Eur Respir Rev 2006;15(99):51-7. http://dx.doi.org/10.1183/09059180.00009906

63. Welte T. Optimising treatment for COPD--new strategies for combination therapy. Int J Clin Pract 2009;63(8):1136-49. http://dx.doi.org/10.1111/j.17421241.2009.02139.x

64. Cazzola M, Tashkin DP. Combination of formoterol and tiotropium in the treatment of COPD: effects on lung function. COPD 2009;6(5):404-15.

65. Cazzola M, Dahl R. Inhaled combination therapy with long-acting beta 2-agonists and corticosteroids in stable COPD. Chest 2004;126(1):220-37. http://dx.doi.org/10.1378/chest.126.1.220

66. Calverley PM, Boonsawat W, Cseke Z, Zhong N, Peterson S, Olsson H. Maintenance therapy with budesonide and formoterol in chronic obstructive pulmonary disease. Eur Respir J 2003;22:912-19. http://dx.doi.org/ 10.1183/09031936.03.00027003

67. Suissa S, McGhan R, Niewoehner D, Make B. Inhaled corticosteroids in chronic obstructive pulmonary disease. Proc Am Thorac Soc 2007;4(7):535-42. http://dx.doi.org/10.1513/pats.200701-024FM

68. Rodrigo GJ, Castro-Rodriguez JA, Plaza V. Safety and efficacy of combined longacting beta-agonists and inhaled corticosteroids vs long-acting beta-agonists monotherapy for stable COPD: a systematic review. Chest 2009;136(4):1029-38. http://dx.doi.org/10.1378/chest.09-0821

69. Singh $S$, Amin AV, Loke YK. Long-term use of inhaled corticosteroids and the risk of pneumonia in chronic obstructive pulmonary disease: a meta-analysis. Arch Intern Med 2009,169(3):219-29. http://dx.doi.org/10.1001/archinternmed.2008.550

70. Drummond MB, Dasenbrook EC, Pitz MW, Murphy DJ, Fan E. Inhaled corticosteroids in patients with stable chronic obstructive pulmonary disease: a systematic review and meta-analysis. JAMA 2008;300(20):2407-16.

71. Sobieraj DM, White CM, Coleman Cl. Benefits and risks of adjunctive inhaled corticosteroids in chronic obstructive pulmonary disease: a meta-analysis. Clin Ther 2008;30(8):1416-25. http://dx.doi.org/10.1016/j.clinthera.2008.08.004

72. Ernst P, Gonzalez AV, Brassard P, Suissa S. Inhaled corticosteroid use in chronic obstructive pulmonary disease and the risk of hospitalization for pneumonia. Am J Respir Crit Care Med 2007;176(2):162-6. http://dx.doi.org/10.1164/rccm.200611$16300 \mathrm{C}$

73. Crim C, Calverley PM, Anderson JA, et al. Pneumonia risk in COPD patients receiving inhaled corticosteroids alone or in combination: TORCH study results. Eur Respir J 2009;34(3):641-7. http://dx.doi.org/10.1183/09031936.00193908

74. Sin DD, Tashkin D, Zhang $X$, et al. Budesonide and the risk of pneumonia: a metaanalysis of individual patient data. Lancet 2009;374(9691):712-19. http://dx.doi.org/10.1016/S0140-6736(09)61250-2

75. Singh D, Brooks J, Hagan G, Cahn A, O'Connor BJ. Superiority of "triple" therapy with salmeterol/fluticasone propionate and tiotropium bromide versus individual components in moderate to severe COPD. Thorax 2008;63(7):592-8. http://dx.doi.org/10.1136/thx.2007.087213

76. Troosters T, Celli B, Kesten S, et al. Effectiveness of combination therapy with tiotropium in COPD. A secondary analysis of the UPLIFT trial. Eur Respir $J$ 2009;34(Suppl 53):675S.

77. Welte $T$, Miravitlles $M$, Hernandez $P$, et al. Efficacy and tolerability of budesonide/formoterol added to tiotropium in patients with chronic obstructive pulmonary disease. Am J Respir Crit Care Med 2009;180(8):741-50. http://dx.doi.org/10.1164/rccm.200904-04920C

78. Perng DW, Wu CC, Su KC, Lee YC, Perng RP, Tao CW. Additive benefits of tiotropium in COPD patients treated with long-acting beta agonists and corticosteroids. Respirology 2006;11(5):598-602.

79. Siafakas NM, Vermeire P, Pride NB, Paoletti P. Optimal assessment and management of chronic obstructive pulmonary disease (COPD). The European Respiratory Society Task Force. Eur Respir J 1995;8:1398-420.

80. Zhou $Y$, Wang $X$, Zeng $X$, et al. Positive benefits of theophylline in a randomized, double-blind, parallel-group, placebo-controlled study of low-dose, slow-release 
theophylline in the treatment of COPD for 1 year. Respirology 2006;11(5):603-10.

81. Glaab T, Banik N, Rutschmann OT, Wencker M. National survey of guidelinecompliant COPD management among pneumologists and primary care physicians. COPD 2006;3(3):141-8.

82. Rutschmann OT, Janssens JP, Vermeulen B, Sarasin FP. Knowledge of guidelines for the management of COPD: a survey of primary care physicians. Respir Med 2004;98(10):932-7. http://dx.doi.org/10.1016/j.rmed.2004.03.018

83. Jones RC, Dickson-Spillmann M, Mather MJ, Marks D, Shackell BS. Accuracy of diagnostic registers and management of chronic obstructive pulmonary disease: the Devon primary care audit. Respir Res 2008;9:62. http://dx.doi.org/ 10.1186/1465-9921-9-62

84. Bourbeau J, Sebaldt RJ, Day A, et al. Practice patterns in the management of chronic obstructive pulmonary disease in primary practice: the CAGE study. Can Respir J 2008;15(1):13-19.

85. Tashkin DP, Celli B, Senn S, et al. A 4-year trial of tiotropium in chronic obstructive pulmonary disease. N Engl J Med 2008;359(15):1543-54. http://dx.doi.org/10.1056/NEJMoa0805800

86. Haahtela $T$, Tuomisto LE, Pietinalho A, et al. A 10 year asthma programme in Finland: major change for the better. Thorax 2006;61(8):663-70. http://dx.doi.org/10.1136/thx.2005.055699

87. Price D, Freeman D, Kaplan A, Ostrem A, Reid J, Molen T. Progressive breathlessness in COPD - the role of hyperinflation and its pharmacological management. Prim Care Resp J 2005;14(6):285-93. http://dx.doi.org/10.1016/j.pcrj.2005.08.005

88. Celli BR, Thomas NE, Anderson JA, et al. Effect of pharmacotherapy on rate of decline of lung function in chronic obstructive pulmonary disease: results from the TORCH study. Am J Respir Crit Care Med 2008;178(4):332-8. http://dx.doi.org/10.1164/rccm.200712-18690C

89. Miravitlles M, Anzueto A. Insights into interventions in managing COPD patients: lessons from the TORCH and UPLIFT studies. Int I Chron Obstruct Pulmon Dis 2009;4:185-201.

90. Morice A, Celli B, Kesten S, et al. COPD patients under 50 years of age: 4-year follow-up in the UPLIFT trial. Eur Respir J 2009;34(Suppl 53):674S.

91. Troosters T, Celli B, Burkhart SD, et al. Effectiveness of tiotropium as first maintenance drug in patients with COPD. Secondary analysis of the UPLIFT trial. Am J Respir Crit Care Med 2009;179:A2467. http://dx.doi.org/10.1016/S09546111(06)80166-6

92. Jones PW, Quirk FH, Baveystock CM. The St. George's Respiratory Questionnaire. Respir Med 1991;85(Suppl $\quad$ B):25-31. http://dx.doi.org/10.1016/S09546111(06)80166-6

93. Novartis. Novartis receives approval in the European Union for Onbrez Breezhaler, a new once-daily bronchodilator for patients with COPD. www.novartis.com. Accessed January 14, 2010.

94. Schering Plough. Product pipeline. www.merck.com. Accessed January 14, 2010.

95. Chiesi. R\&D pipeline 2009. www.chiesigroup.com. Accessed January 14, 2010.

96. Nycomed. Pipeline overview. Key pipeline products. www.nycomed.com. Accessed January 14, 2010.

97. Almirall. Product development pipeline. www.almirall.com. Accessed January 14, 2010.

98. Mullard A. GSK drops daratropium in favour of GSK573719 for COPD. www.scripnews.com. Accessed January 14, 2010.

99. GlaxoSmithKline. Product development pipeline. www.gsk.com. Accessed January $14,2010$.

100. Novartis. Clinical pipeline. Planned filings. www.novartis.com. Accessed January $14,2010$.

101. A dose-finding study evaluating safety and efficacy in patients with chronic obstructive pulmonary disease (NCT00403286). www.clinicaltrials.gov. Accessed January 14, 2010.

102. Combination of orally inhaled Bl1744Cl/tiotropium bromide in patients with chronic obstructive pulmonary disease (COPD) (NCT00696020). www.clinicaltrials.gov. Accessed January 14, 2010.

103. Efficacy and safety of 4 weeks treatment with inhaled BI $1744 \mathrm{CL}$ in patients with COPD (NCT00452400). www.clinicaltrials.gov. Accessed January 14, 2010.

104. Rennard S, Bantje T, Centanni S, et al. A dose-ranging study of indacaterol in obstructive airways disease, with a tiotropium comparison. Respir Med 2008;102(7):1033-44. http://dx.doi.org/10.1016/j.rmed.2008.02.001

105. Barnes $\mathrm{P}$, Pocock S, Magnussen $\mathrm{H}$, et al. Indacaterol dose selection: utilising an adaptive seamless design in a clinical study in COPD. Eur Respir J 2009;34(Suppl 53): $778 \mathrm{~s}$

106. Fogarty C, Hebert J, Iqbal A, Owen R, Higgins M, Kramer B. Indacaterol once-daily provides effective 24-h bronchodilation in COPD patients: a 26-week evaluation vs placebo and tiotropium. Eur Respir J 2009;34(Suppl 53):345s.

107. Yorgancioglu A, Mahler,D, Iqbal A, Owen R, Higgins M, Kramer B. Indacaterol once-daily improves health-related quality of life in COPD patients: a 26-week comparison with placebo and tiotropium. Eur Respir J 2009;34(Suppl 53):346s.

108. Mahler D, Palange P, lqbal A, Owen R, Higgins M, Kramer B. Indacaterol once-daily improves dyspnoea in COPD patients: a 26-week placebo-controlled study with open-label tiotropium comparison. Eur Respir J 2009;34(Suppl 53):779s.

109. Dahl R, Kolman P, Jack D, et al. Bronchodilator therapy with indacaterol once-daily in COPD: a 52-week comparison with formoterol. Eur Respir J 2009;34(Suppl 53):776s-777s

110. Nonikov $V$, Verkindre C, Jack $D$, et al. Indacaterol once-daily improves symptom control in COPD patients: a 52-week evaluation vs placebo (pbo) and formoterol (for). Eur Respir J 2009;34(Suppl 53):345s.

111. Magnussen $H$, Paggiaro $P$, Jack D, Owen R, Higgins M, Kramer B. Indacaterol oncedaily improves health-related quality of life (HRQOL) in COPD patients: a 52-week study. Eur Respir J 2009;34(Suppl 53):344s.

112. Buhl R, Pieters W, Jack D, Owen R, Kramer B, Higgins M. Indacaterol once-daily improves dyspnoea and BODE index in COPD patients: a 52-week study. Eur Respir J 2009;34(Suppl 53):345s-346s.

113. Chung F, Kornmann O, Jack D, Owen R, Kramer B, Higgins M. Safety and tolerability of indacaterol over 52 weeks of treatment in COPD. Eur Respir $J$ 2009;34(Suppl 53):778s-779s

114. Worth H, Kleerup E, Iqbal A, Owen R, Kramer B, Higgins M. Safety and tolerability of indacaterol once-daily in COPD patients versus placebo and tiotropium: a 26week study. Eur Respir J 2009;34(Suppl 53):346s.

115. Lipworth BJ. Phosphodiesterase-4 inhibitors for asthma and chronic obstructive pulmonary disease. Lancet 2005;365(9454):167-75. http://dx.doi.org/10.1016/ S0140-6736(05)17708-3

116. European Medicines Agency and Committee for Medicinal Products for Human Use. Summary of opinion (initial authorisation). Daxas. Roflumilast. European Medicines Agency. Available from: http://www.ema.europa.eu. Accessed 12 May 2010.

117. Calverley PM, Rabe KF, Goehring UM, Kristiansen S, Fabbri LM, Martinez FJ. Roflumilast in symptomatic chronic obstructive pulmonary disease: two randomised clinical trials. Lancet 2009;374(9691):685-94. http://dx.doi.org/10.1016/S0140-6736(09)61255-1

118. Hodder R, Kesten S, Menjoge S, Viel K. Outcomes in COPD patients receiving tiotropium or salmeterol plus treatment with inhaled corticosteroids. Int J Chron Obstruct Pulmon Dis 2007;2(2):157-67.

119. Tashkin DP, Celli B, Kesten S, Lystig T, Mehra S, Decramer M. Long-term efficacy of tiotropium in relation to smoking status in the UPLIFT trial. Eur Respir $J$ 2010;35:287-94. http://dx.doi.org/10.1183/09031936.00082909

120. Rabe KF, Bateman ED, O'Donnell D, Witte S, Bredenbroker D, Bethke TD. Roflumilast--an oral anti-inflammatory treatment for chronic obstructive pulmonary disease: a randomised controlled trial. Lancet 2005;366(9485):563-71. http://dx.doi.org/10.1016/S0140-6736(05)67100-0

121. Fabbri LM, Calverley PM, Izquierdo-Alonso JL, et al. Roflumilast in moderate-tosevere chronic obstructive pulmonary disease treated with longacting bronchodilators: two randomised clinical trials. Lancet 2009;374(9691):695-703. 
http://dx.doi.org/10.1016/S0140-6736(09)61252-6

122. Rennard S, Donohue J, Bateman E, Gross N, Garcia-Gil E, Caracta C. ACCLAIM/COPD II: Efficacy and safety of aclidinium bromide, a novel, long-acting muscarinic antagonist in COPD patients, a Phase III study. Eur Respir J 2009;34(Suppl 53):777s.

123. Jones $P$, Agusti J, Chanez $P$, et al. Efficacy and safety of aclidinium bromide, a novel long-acting muscarinic antagonist, in patients with moderate to severe COPD. Eur Respir J 2009;34(Suppl 53):345s.

124. Vestbo J, Vogelmeier C, Creemers J, Ribera A, Garcia-Gil E. Rate of onset of action of aclidinium bromide, a novel, long-acting muscarinic antagonist. Eur Respir J 2009;34(Suppl 53):779s.

125. Aaron SD, Vandemheen KL, Fergusson D, et al. Tiotropium in combination with placebo, salmeterol, or fluticasone-salmeterol for treatment of chronic obstructive pulmonary disease: a randomized trial. Ann Intern Med 2007;146(8):545-55.

126. de Marco R, Accordini S, Cerveri I, et al. An international survey of chronic obstructive pulmonary disease in young adults according to GOLD stages. Thorax 2004;59(2):120-5. http://dx.doi.org/10.1136/thorax.2003.011163

127. Calverley PM. COPD: early detection and intervention. Chest 2000;117(5 Suppl 2):365S-71S. http://dx.doi.org/10.1378/chest.117.5_suppl_2.365S

128. Miravitlles M, De la RC, Naberan K, Lamban M, Gobartt E, Martin A, Chapman KR. Attitudes toward the diagnosis of chronic obstructive pulmonary disease in primary care. Arch Bronconeumol 2006;42(1):3-8. http://dx.doi.org/10.1016/S15792129(06)60106-7

129. van Schayck CP, Loozen JMC, Wagena E, Akkermans RP, Wesseling GJ. Detecting patients at a high risk of developing chronic obstructive pulmonary disease in general practice: cross sectional case finding study. Br Med J 2002;324:1370-4.

130. Buffels J, Degryse J, Heyrman J, Decramer M. Office spirometry significantly improves early detection of COPD in general practice: the DIDASCO Study. Chest 2004;125(4):1394-9. http://dx.doi.org/10.1378/chest.125.4.1394

131. Kaufmann M, Hartl S, Geyer K, Breyer MK, Burghuber OC. Measuring FEV(6) for detecting early airway obstruction in the primary care setting. Quality and utility of the new PiKo-6 device. Respiration 2009;78(2):161-7. http://dx.doi.org/10.1159/000197466

132. Price D, Crockett A, Arne $M$, et al. Spirometry in primary care case-identification, diagnosis and management of COPD. Prim Care Resp J 2009;18(3):216-23. http://dx.doi.org/10.4104/pcrj.2009.00055

133. George J, Kong DC, Thoman R, Stewart K. Factors associated with medication nonadherence in patients with COPD. Chest 2005;128(5):3198-204. http://dx.doi.org/10.1378/chest.128.5.3198

134. George J, Kong DC, Stewart K. Adherence to disease management programs in patients with COPD. Int J Chron Obstruct Pulmon Dis 2007;2(3):253-62.

135. Vestbo J, Anderson JA, Calverley PM, et al. Adherence to inhaled therapy, mortality and hospital admission in COPD. Thorax 2009;64(11):939-43. http://dx.doi.org/10.1136/thx.2009.113662

136. Celli B. Chronic obstructive pulmonary disease. From unjustified nihilism to evidence-based optimism. Proc Am Thorac Soc 2006;3:58-65. http://dx.doi.org/10.1513/pats.200510-111JH

137. Kohansal R, Martinez-Camblor P, Agusti A, Buist AS, Mannino DM, Soriano JB. The natural history of chronic airflow obstruction revisited: an analysis of the Framingham offspring cohort. Am J Respir Crit Care Med 2009;180(1):3-10. http://dx.doi.org/10.1164/rccm.200901-00470C

138. Barnes PJ, Drazen JM, Rennard SI, Thomson NC. Asthma and COPD, second edition: Basic mechanisms and clinical management.: Academic Press, 2008

\section{Available online at http://www.thepcrj.org}

